\title{
Reactive Oxygen Species Derived from NOX1/NADPH Oxidase Enhance Inflammatory Pain
}

\author{
Masakazu Ibi, ${ }^{1}$ Kuniharu Matsuno, ${ }^{1}$ Dai Shiba, ${ }^{2}$ Masato Katsuyama, ${ }^{1}$ Kazumi Iwata, ${ }^{1}$ Tomoko Kakehi, ${ }^{1}$ \\ Takayuki Nakagawa, ${ }^{3}$ Kazunori Sango, ${ }^{4}$ Yasuhito Shirai, ${ }^{5}$ Takahiko Yokoyama, ${ }^{2}$ Shuji Kaneko, ${ }^{3}$ Naoaki Saito, ${ }^{5}$ and \\ Chihiro Yabe-Nishimura ${ }^{1}$ \\ Departments of ${ }^{1}$ Pharmacology and ${ }^{2}$ Anatomy and Developmental Biology, Kyoto Prefectural University of Medicine, Kyoto 602-8566, Japan, ${ }^{3}$ Department \\ of Molecular Pharmacology, Graduate School of Pharmaceutical Science, Kyoto University, Kyoto 606-8501, Japan, ${ }^{4}$ Department of Developmental \\ Morphology, Tokyo Metropolitan Institute for Neuroscience, Tokyo 183-8526, Japan, and ${ }^{5}$ Laboratory of Molecular Pharmacology, Biosignal Research \\ Center, Kobe University, Kobe 657-8501, Japan
}

The involvement of reactive oxygen species (ROS) in an augmented sensitivity to painful stimuli (hyperalgesia) during inflammation has been suggested, yet how and where ROS affect the pain signaling remain unknown. Here we report a novel role for the superoxidegenerating NADPH oxidase in the development of hyperalgesia. In mice lacking Nox1 (Nox1 ${ }^{-/ Y}$ ), a catalytic subunit of NADPH oxidase, thermal and mechanical hyperalgesia was significantly attenuated, whereas no change in nociceptive responses to heat or mechanical stimuli was observed. In dorsal root ganglia (DRG) neurons of $\mathrm{Nox}^{+/ Y}$, pretreatment with chemical mediators bradykinin, serotonin, or phorbol 12-myristate 13-acetate (PMA) augmented the capsaicin-induced calcium increase, whereas this increase was significantly attenuated in DRG neurons of $N o x 1^{-/ Y}$. Concomitantly, PMA-induced translocation of PKC $\varepsilon$ was markedly perturbed in Nox1 ${ }^{-/ Y}$ or Nox $1^{+/ Y}$ DRG neurons treated with ROS-scavenging agents. In cells transfected with tagged PKC $\varepsilon$, hydrogen peroxide induced translocation and a reduction in free sulfhydryls of full-length PKC $\varepsilon$ but not of the deletion mutant lacking the C1A domain. These findings indicate that NOX1/NADPH oxidase accelerates the translocation of PKC $\varepsilon$ in DRG neurons, thereby enhancing the TRPV1 activity and the sensitivity to painful stimuli.

Key words: NOX1; NADPH oxidase; PKCe; TRPV1; hyperalgesia; inflammation

\section{Introduction}

An augmented sensitivity to painful stimuli (hyperalgesia) is characteristic of inflammatory pain and persists until the tissue heals. Chemical mediators released from damaged tissue and inflammatory cells enhance the perception of pain by decreasing the activation threshold of transient receptor potential vanilloid 1 (TRPV1) through a variety of posttranslational mechanisms (Cesare and McNaughton, 1996; Khasar et al., 1999; Hu et al., 2002; Chuang et al., 2001; Ohta et al., 2006). Among these mechanisms, protein kinase A (PKA)- and PKC-mediated phosphorylation of serine residues is known to modulate the sensitivity of TRPV1 (Bhave et al., 2002; Numazaki et al., 2002). TRPV1 is a nonselective cation channel with six transmembrane domains expressed predominantly in $\mathrm{A} \delta$-fibers and unmyelinated C-fibers. It is activated by several stimuli, including heat $\left(>43^{\circ} \mathrm{C}\right)$, capsaicin, and protons. Mice with a disruption in the trpv1 gene were incapable

Received April 28, 2008; revised Aug. 4, 2008; accepted Aug. 4, 2008.

This work was partly supported by Grant-in-Aid for Young Scientists (B) 17790172 from the Ministry of Education, Culture, Sports, Science, and Technology of Japan (M.I.). We thank Dr. D. Lambeth at Emory University and Dr. K. Rokutan at Tokushima University for providing anti-NOX1 antibodies, and Dr. M. Tominaga at Okazaki Institute for Integrative Bioscience for insightful discussions and critical reading of this manuscript.

Correspondence should be addressed to Dr. Chihiro Yabe-Nishimura, Department of Pharmacology, Kyoto Prefectural University of Medicine, Kamigyo-ku, Kyoto 602-8566, Japan. E-mail address: nchihiro@koto.kpu-m.ac.jp. DOI:10.1523/JNEUROSCI.1857-08.2008

Copyright $\odot 2008$ Society for Neuroscience $\quad$ 0270-6474/08/289486-09\$15.00/0 of sensing capsaicin and showed little thermal hypersensitivity during inflammation (Caterina et al., 2000).

The involvement of reactive oxygen species (ROS) in nociceptive signaling has been reported in recent studies. The application of a compound that mimics the enzymatic activity of superoxide dismutase (SOD) or a radical scavenger TEMPOL attenuated hyperalgesia elicited by injection of an inflammatory agent, carrageenan (Wang et al., 2004; Khattab, 2006). Nitration of endogenous manganese $(\mathrm{Mn}) \mathrm{SOD}$ in the spinal cord during carrageenan-induced hyperalgesia deactivates the enzyme, allowing superoxide levels to remain elevated and sustain nociceptive signaling (Wang et al., 2004). Although these results suggest that ROS mediate pain that accompanies inflammation, important issues left unanswered include the source of ROS and how ROS are involved in pain signaling.

$\mathrm{NADPH}$ oxidase is a superoxide-generating flavoenzyme comprising a membrane-bound catalytic subunit NOX and several cytosolic regulatory subunits. Among several homologs of NOX identified so far, NOX2 has been implicated in various neurodegenerative disorders such as Parkinson's disease, Alzheimer's disease, and amyotrophic lateral sclerosis (Wu et al., 2002, 2006; Abramov et al., 2004). In contrast, a relative paucity of data exists on the role of NOX1. NOX1 is primarily expressed in colon epithelial cells and to a lesser extent in vascular smooth muscle cells (Lambeth, 2004). In a preceding work using cultured neu- 
ronal cells, we found an intriguing role for NOX1 in nerve growth factor (NGF)-induced neurite outgrowth (Ibi et al., 2006). Increased superoxide generation after upregulation of NOX1 induced by NGF negatively regulated neuronal differentiation by suppressing excessive neurite outgrowth. As an extension of this study, we investigated whether NOX1/NADPH oxidase is involved in neuronal development and signaling using mice deficient in the Noxl gene (Nox1 ${ }^{-/ Y}$ ) (Matsuno et al., 2005). Based on the findings obtained in these mice and cultured cells, we report here a novel role for this superoxide-generating enzyme in the development of inflammatory pain.

\section{Materials and Methods}

Reagents. Ham's F-12 medium, DMEM/F-12, horse serum, and SuperScript III Platinum SYBR Green One-Step qRT-PCR were obtained from Invitrogen. Fura-2 AM was purchased from Dojindo. Neuronal-specific nuclear protein (NeuN) was purchased from Millipore Bioscience Research Reagents. Anti-TRPV1 antibody was obtained from Calbiochem. Bradykinin, phorbol 12-myristate 13-acetate (PMA), SOD-polyethylene glycol (PEG), catalase-PEG, cholera toxin B-FITC, isolectin B4 (IB4)FITC, diphenyleneiodonium (DPI) chloride, NADPH, N-acetyl-Lcysteine, dithiothreitol, and streptavidin-agarose were obtained from Sigma. Carrageenan, Formalin, and acetic acid were purchased from Wako Pure Chemicals. Anti-PKC $\varepsilon$ antibody, anti-PKC $\delta$ antibody, and anti-NOX1 antibody were obtained from Santa Cruz Biotechnology. EZLink PEO-iodoacetyl Biotin was obtained from Pierce. Anti-PKC $\alpha$ antibody was obtained from BD Biosciences. TransIT-LT1 reagent was purchased from Mirus. Anti-NOX1 antibodies were also provided by Dr. D. Lambeth (Emory University, Atlanta, GA) and Dr. K. Rokutan (Tokushima University, Tokushima, Japan).

Animals. Mice deficient in Nox1 $\left(\mathrm{Nox}^{-/ Y}\right)$ and control littermates $\left(\mathrm{Noxl}^{+/ Y}\right)$ were housed in a temperature-controlled room $\left(21-23^{\circ} \mathrm{C}\right)$ with a $12 \mathrm{~h}$ light/dark cycle. For behavioral and neural culture studies, $11-$ to 12 -week-old animals were used. All procedures were done in accordance with the policies and recommendations of the International Association for the Study of Pain and were approved by the Committee for Animal Research at Kyoto Prefectural University of Medicine.

Morphological analysis. Mice were perfused with $4 \%$ paraformaldehyde in $0.1 \mathrm{~m}$ phosphate buffer. L4 and L5 DRG were removed, soaked in $20 \%$ sucrose overnight, and stored at $-80^{\circ} \mathrm{C}$. Sections $(10 \mu \mathrm{m})$ were stained with $0.1 \%$ toluidine blue for $10 \mathrm{~min}$. NIH ImageJ software was used for the measurement of neuron area.

Paraformaldehyde-perfused cryosections were used for immunohistochemical analyses for NeuN and TRPV1. Sections were first incubated with $\mathrm{NeuN}(1: 200)$ for $24 \mathrm{~h}$ at $4^{\circ} \mathrm{C}$ in a blocking buffer followed by blocking with $1 \%$ goat serum in $0.1 \%$ Triton X-100/PBS. After being washed with PBS, sections were reacted with anti-mouse IgG conjugated with Alexa488 (1:400) for $1 \mathrm{~h}$ at room temperature. After another wash and further blocking, incubation of anti-TRPV1 antibody (1:200) in blocking buffer was performed for $2 \mathrm{~h}$ at room temperature. Sections were washed with PBS and further incubated with Alexa568-conjugated $\operatorname{IgG}(1: 400)$ for $1 \mathrm{~h}$. After a final wash with PBS, fluorescence was detected with FV1000 (Olympus).

Analysis of motor function. Initially, mice deficient in Nox1 were tested for locomotor activity and coordinated movement. Spontaneous locomotor activity was determined in a $25 \times 40 \mathrm{~cm}$ field for 5 min using ACTMONITOR II (Medical Agent). A rotarod test was performed to examine coordinated movement according to a method described previously with minor modifications (Kuribara et al., 1977). The rod rotated with a stepwise increase in speed from 8 to $16 \mathrm{rpm}$ every $5 \mathrm{~min}$, and coordinated movement was determined as the time taken to fall from the rod at each speed.

Thermal, mechanical, and chemical nociception. The tail-flick test was performed using a Tail Flick Analgesia Meter (Muromachi). The tail at $3.5 \mathrm{~cm}$ from the tip was exposed to radiant heat, and the latency of escape from stimuli was measured. The cutoff time was $15 \mathrm{~s}$. The hotplate test was performed at three different temperatures $\left(50,52\right.$, and $\left.55^{\circ} \mathrm{C}\right)$. The latency of licking the hindpaw was recorded. The cutoff time was $60 \mathrm{~s}$ for $50^{\circ} \mathrm{C}, 40 \mathrm{~s}$ for $52^{\circ} \mathrm{C}$, and $20 \mathrm{~s}$ for $55^{\circ} \mathrm{C}$. Tail pressure was added using Randall Selitto (Ugo Basile). Pressure was gradually applied to the tail of mice, and nociceptive thresholds were determined as the pressure (grams) required to elicit tail withdrawal. The cutoff weight was $200 \mathrm{~g}$. To evaluate chemical nociception, acetic acid $(0.6 \%)$ was intraperitoneally injected $(0.1 \mathrm{ml} / 10 \mathrm{~g})$, and the number of writhes was counted for 20 min. Formalin (10 $\mu \mathrm{l}$ of $0.5 \%$ Formalin in saline) was intraplantarly injected under brief ether anesthesia. Mice were subsequently transferred to observation cages, and the time of each lick or bite of the hindpaw during $0-10 \mathrm{~min}$ (phase 1) and 20-50 min (phase 2) after injection was measured and integrated.

Carrageenan-induced hyperalgesia. Carrageenan ( $2 \%$ in $30 \mu \mathrm{l}$ of saline) was injected subcutaneously into the plantar area of the right hindpaw of mice anesthetized with ether. The paw volume was measured with a plethysmometer (Ugo Basile) before the injection of carrageenan and every hour after the injection up to $5 \mathrm{~h}$ (Salvemini et al., 1996). The magnitude of edema was expressed by $\left(V_{\text {post }}-V_{\text {pre }}\right) / V_{\text {pre }} \times 100$, where $V_{\text {pre }}$ and $V_{\text {post }}$ are the volume of the paw measured before and after carrageenan injection, respectively.

To evaluate thermal hyperalgesia, the hindpaw withdrawal latency was measured by the method of Hargreaves et al. (1988) using a Paw Stimulator Analgesia Meter (IITC). After habituation, a hindpaw was exposed to radiant heat, and the latency of escape from the stimulus was measured. Mechanical hyperalgesia was evaluated using a $0.6 \mathrm{~g}$ von Frey hair (Muromachi) as described previously (Takasaki et al., 2000). A mouse was placed in a cage with a wire mesh bottom. After acclimation for at least $30 \mathrm{~min}$, the $0.6 \mathrm{~g}$ von Frey hair (Muromachi) was pressed perpendicularly against the plantar skin and held for 3-5 s slightly buckled. Stimulation of the same intensity was applied six times to each hindpaw at intervals of several seconds. Responses to stimuli were ranked as follows: 0 , no response; 1 , movement away from the von Frey hair; and 2, immediate flinching or licking of the hindpaw. The pain score was calculated as follows: pain score $(\%)=\Sigma($ average score of each animal $) / 2 \times$ (number of animals tested) $\times 100$.

Real-time PCR. Total RNA was isolated from DRG by the acid guanidinium thiocyanate/phenol/chloroform method. Real-time PCR was performed by use of the GeneAmp 5700 Sequence Detection System (Applied Biosystems) with the SuperScript III Platinum SYBR Green One-Step qRT-PCR kit (Invitrogen). The primer sequences used were as follows: Nox1, 5' -ctgacaagtactattacacgagag- $3^{\prime}$ and $5^{\prime}$-catatatgccaccagcttatggaag- $3^{\prime}$; Nox2, $5^{\prime}$-aactgtatgctgatcctgctgc- $3^{\prime}$ and $5^{\prime}$-gttctcattgtcaccgatgtcag-3'; Nox4, 5' -tgaggagtcactgaactatgaagttaatc- $3^{\prime}$ and $5^{\prime}$ tgactgaggtacagctggatgttcaca- $3^{\prime}$. Copy number was calculated on the basis of standard curves generated using mouse Nox1, Nox2, and Nox 4 cDNA templates. Data were expressed as copies per microgram RNA.

Cell culture and transfections. The isolation of DRG neurons was performed as described with minor modifications (Sango et al., 2004). Briefly, DRG at thoracolumbar and lumber levels were isolated from 12 -week-old mice, incubated with collagenase at $37^{\circ} \mathrm{C}$ for $90 \mathrm{~min}$, and digested with $0.05 \%$ trypsin for $10 \mathrm{~min}$. Dispersed cells were resuspended in F-12/Ham's medium containing $10 \%$ FBS and then plated on poly-Llysine-coated dishes. Experiments were performed 1-2 d after the preparation of neuronal cultures.

HEK293 and CHO cells were maintained in 10\% FBS-containing Eagle's medium essential medium and Ham's F-12, respectively. These cells were transfected with the green fluorescent protein (GFP)-tagged PKC $\varepsilon$ expression vectors (Kashiwagi et al., 2002) using TransIT-LT1 reagent according to the instructions of the manufacturer. After $24-48 \mathrm{~h}$, transfected cells were exposed to hydrogen peroxide.

Measurement of superoxide by lucigenin luminescence. Extracellular superoxide production by DRG neurons was evaluated by measuring lucigenin luminescence using a Luminescensor (Atto). DRG neurons $(5 \times$ $10^{3}$ cells) at day 1 in vitro were harvested with trypsin and washed twice with HBSS. Cells were suspended in 1\% BSA/HBSS containing $100 \mu \mathrm{M}$ $\mathrm{NADPH}$ and $1 \mu \mathrm{M}$ lucigenin. Chemiluminescence was measured at $37^{\circ} \mathrm{C}$ for $10 \mathrm{~min}$ and expressed as relative light counts per $5 \mathrm{~min}$.

Immunoblot for TRPV1. The supernatant fraction of DRG neurons homogenized in lysis buffer ( $25 \mathrm{~mm} \beta$-glycerophosphate, 2 mм EGTA, $1 \%$ Triton X-100, $1 \mathrm{~mm}$ PMSF, and $2 \mathrm{~mm}$ DTT in $20 \mathrm{~mm}$ TBS) was 
separated by SDS-PAGE and transferred to polyvinylidene difluoride membranes. An anti-TRPV1 monoclonal antibody and antimouse IgG antibody were used for detection with ECL-Plus (GE Healthcare). The density of the band was analyzed using NIH Image J software.

Measurement of intracellular calcium. DRG neurons were loaded with $5 \mu \mathrm{M}$ fura-2 $\mathrm{AM}$ at $37^{\circ} \mathrm{C}$ for 30 min in DMEM/F-12 medium containing 1\% BSA. Ratiometric fluorescence images were captured at $3 \mathrm{~s}$ intervals by alternate excitation at 340 and $380 \mathrm{~nm}$, with emission at $510 \mathrm{~nm}$. The fluorescence of fura-2 associated with individual cells was determined by Metafluor imaging software. Results were expressed as the $340 \mathrm{~nm} / 380 \mathrm{~nm}$ emission ratio, which is proportional to the intracellular calcium concentration $\left(\left[\mathrm{Ca}^{2+}\right]_{\mathrm{i}}\right)$ (Zhang et al., 2005). Forskolin (10 $\mu \mathrm{M})$, PMA (100 nM), bradykinin $(10 \mu \mathrm{M})$, or serotonin $(30 \mu \mathrm{M})$ was applied to the medium before the addition of $3 \mathrm{~nm}$ capsaicin.

Localization of PKC $\varepsilon$. DRG neurons, starved in a serum-free medium for $3 \mathrm{~h}$ before the analysis, were incubated with $100 \mathrm{~nm}$ PMA for 5 min. ROS-scavenging agents $(300 \mathrm{mU} / \mathrm{ml}$ SOD-PEG, $300 \mathrm{mU} / \mathrm{ml}$ catalase-PEG, $10 \mathrm{~mm}$ $\mathrm{N}$-acetyl cysteine, and $1 \mathrm{~mm}$ dithiothreitol) were included in the medium $3 \mathrm{~h}$ before the addition of 100 nm PMA. After PMA treatment, DRG neurons were fixed and treated as described previously (Rathee et al., 2002). Anti$\mathrm{PKC} \varepsilon$ antibody (1:400 in 3\% BSA) and a secondary anti-rabbit IgG conjugated to Alexa548 (1:400) were used to detect the localization of PKC $\varepsilon$. The fluorescence intensity of the cells was analyzed by selecting a straight line across the neural soma and using the plot profile function of NIH Image J software. Membrane regions were initially identified by IB4-FITC binding, which gave more than threefold higher fluorescence intensity than the background. Average fluorescence intensity of the membrane region $(\Delta F)$ against the total fluorescence intensity across a line bisecting the neural soma $(F)$ was demonstrated. Small neurons of $r<10$ $\mu \mathrm{m}$ were selected to evaluate the translocation of PKC $\varepsilon$, because most small neurons express TRPV1 (Tominaga et al., 1998).

Transfected CHO cells were starved in serum-free medium for $3 \mathrm{~h}$ and exposed to $100 \mu \mathrm{M} \mathrm{H}_{2} \mathrm{O}_{2}$ for $2 \mathrm{~min}$. After fixation, $\mathrm{H}_{2} \mathrm{O}_{2}$-induced translocation of the GFP-tagged full-length $\mathrm{PKC} \varepsilon$ or deletion mutant lacking the C1A domain was visualized by confocal microscopy.

Identification of free sulfhydryl groups in PKCE. The detection of free sulfhydryl groups in $\mathrm{PKC} \varepsilon$ was performed as described previously with modifications (Kim et al., 2001). HEK293 cells were exposed to $100 \mu \mathrm{M} \mathrm{H}_{2} \mathrm{O}_{2}$ for $5 \mathrm{~min}$ and harvested with lysis buffer without a reducing agent. Cell lysate $(250 \mu \mathrm{g})$ was incubated with $500 \mu \mathrm{g}$ of EZ-Link PEO-iodoacetyl Biotin for $16 \mathrm{~h}$ at $4^{\circ} \mathrm{C}$ and then incubated with $40 \mu \mathrm{l}$ of streptavidin-agarose for $4 \mathrm{~h}$ at $4^{\circ} \mathrm{C}$. The beads were washed twice with lysis buffer, and bound protein was eluted with sample buffer. To detect free sulfhydryls in $\mathrm{PKC} \varepsilon$, the eluted sample was subjected to SDS-PAGE and immunoblotted with anti-PKC $\varepsilon$ antibody.

Statistics. Statistical analyses were performed with one-way ANOVA. For multiple datasets, a post hoc multiple comparison (Dunnett's test) was applied. Values are expressed as means \pm SEM. Relative light units.
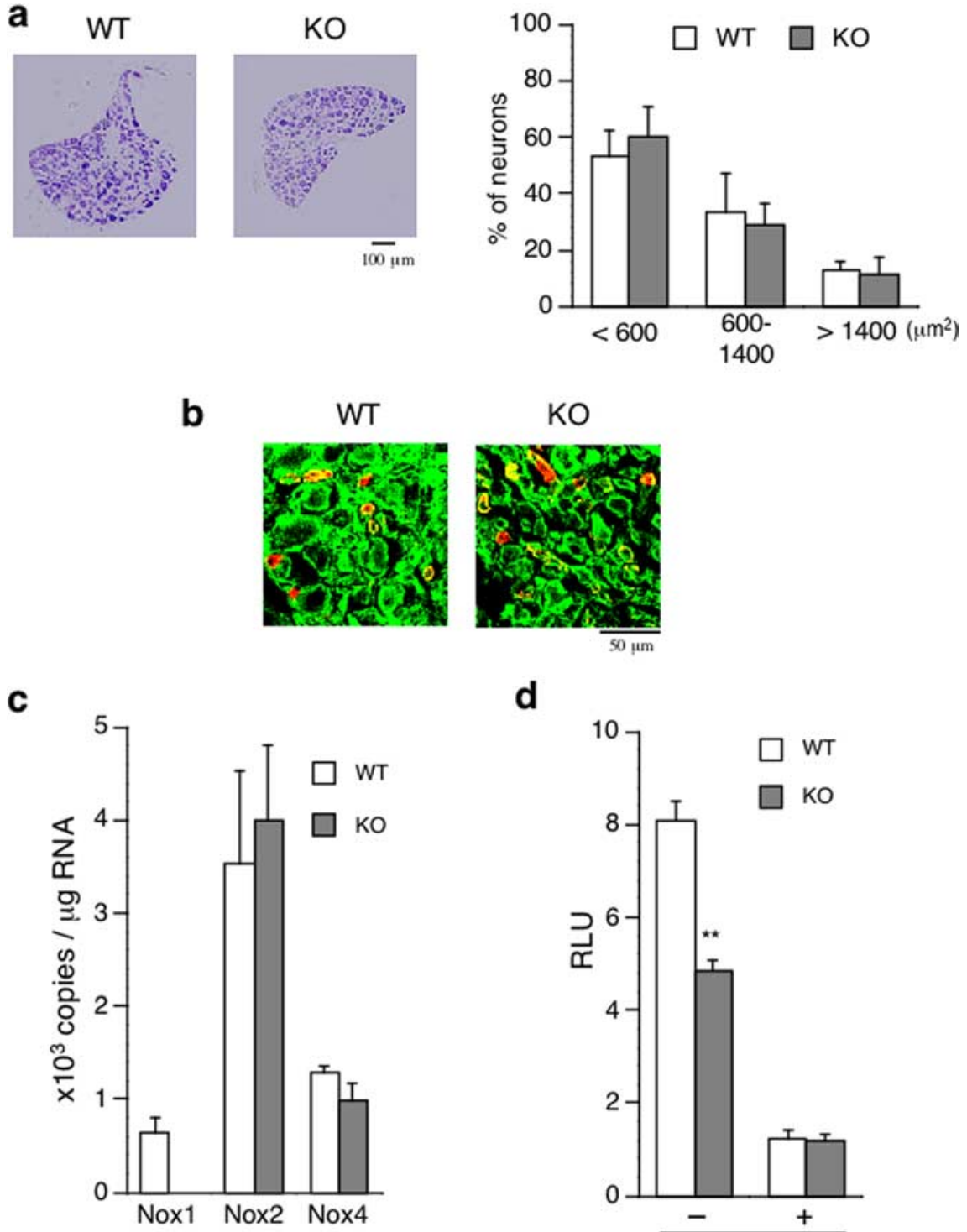

d

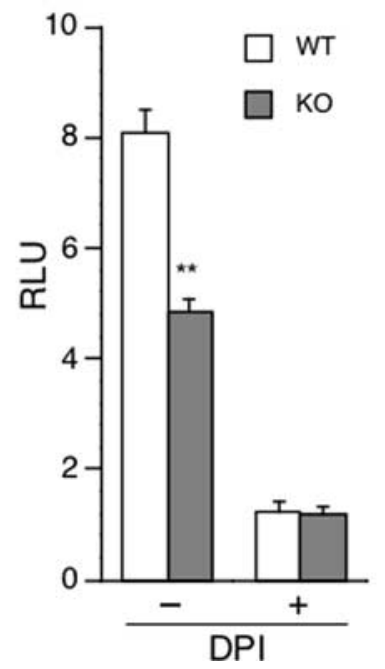

Figure 1. Morphology, expression of Nox isoforms, and superoxide production in DRG of Nox $1^{+/ Y}$ and $N o x 1^{-/ Y}$. $\boldsymbol{a}$, DRG DRG neurons measured with lucigenin in the absence or presence of DPI $(10 \mu \mathrm{M})$. WT (wild-type) and KO (knock-out) represent control littermate $\left(N o \times 1^{+/ Y}\right)$ and Nox1-deficient $\left(N o \times 1^{-/ Y}\right)$ mice, respectively. Values were obtained from four samples. RLU,

\section{Results}

\section{Morphology, expression of Nox isoforms, and superoxide production in DRG}

We first examined whether the deletion of Nox 1 altered the morphology and expression of other Nox isoforms in DRG. Measurement of cell area stained with toluidine blue by the NIH Image software depicted no difference between the two genotypes in the size distribution of DRG neurons (Fig. 1a). In immunohistochemical analyses (Fig. 1b), the population of TRPV1-positive neurons, which reacted with both anti-TRPV1 antibody and NeuN antibody, was also equivalent in both genotypes (26.31 \pm $4.28 \%$ in $\mathrm{Noxl}^{+/ Y}$ vs $24.76 \pm 1.96 \%$ in Noxi ${ }^{-/ Y}$; $\left.n=4\right)$.

In quantitative reverse transcription-PCR analyses, the level of Nox2 mRNA was highest, whereas levels of Nox1 and Nox4 mRNAs were comparable in $N o x 1^{+/ Y}$ DRG. Between the two genotypes, no marked difference was observed in the levels of 
Table 1. Motor function of $\operatorname{Nox} 1^{+N}$ and $N o \times 1^{-N}$

\begin{tabular}{|c|c|c|c|c|}
\hline & \multirow{3}{*}{$\begin{array}{l}\text { Locomotor activity } \\
\text { Counts }\end{array}$} & \multicolumn{3}{|c|}{ Coordinated movement } \\
\hline & & \multicolumn{3}{|c|}{ Latency to fall (s) } \\
\hline & & $8 \mathrm{rpm}$ & 12 rpm & $16 \mathrm{rpm}$ \\
\hline Wild types & $1504.0 \pm 35.0$ & $286.7 \pm 13.2$ & $193.5 \pm 30.4$ & $182.1 \pm 30.5$ \\
\hline Knock-outs & $1504.5 \pm 43.7$ & $291.0 \pm 9.0$ & $222.6 \pm 30.5$ & $206.6 \pm 30.3$ \\
\hline
\end{tabular}

Values were obtained from 11-12 animals per group.

Nox2 and Nox4 mRNAs (Fig. 1c). When the level of Nox1 mRNA expressed in the peripheral nerve was investigated, the level expressed in the spinal cord was much less than that expressed in DRG (data not shown). We further examined the levels of Nox mRNAs expressed in the paw. Nox 1 mRNA $\left(1.34 \pm 0.14 \times 10^{4}\right.$ copies/ $\mu \mathrm{g}$ RNA) was abundantly expressed in the paw compared with DRG $\left(0.65 \pm 0.14 \times 10^{3}\right.$ copies $/ \mu \mathrm{g}$ RNA $)$. Similarly, Nox2 $\left(1.14 \pm 0.13 \times 10^{6}\right.$ in paw vs $3.53 \pm 1.01 \times 10^{3}$ in DRG) and $\operatorname{Nox} 4\left(1.26 \pm 0.17 \times 10^{5}\right.$ in paw vs $1.28 \pm 0.07 \times 10^{3}$ in DRG) mRNAs are highly expressed in the paw tissue. The localization and distribution of NOX1 protein could not be identified by immunohistochemical means using three anti-NOX1 antibodies obtained from different sources. Conversely, the DPI-sensitive extracellular production of superoxide was significantly attenuated in Nox1 ${ }^{-/ Y}$ DRG (Fig. 1d).

\section{Motor function tests}

Because motor function of each animal affects the results obtained in behavioral studies, we first examined the integrity of motor function in both genotypes. As shown in Table 1, no difference in locomotor activity and coordinated movement was found between $N o x 1^{+/ Y}$ and $N_{o x} 1^{-/ Y}$. In addition, the number of mice that remained on the rod at speeds up to $16 \mathrm{rpm}$ in coordinated movement test was equivalent in both genotypes (data not shown).

\section{Thermal, mechanical, and chemical nociception}

No change was observed in $\mathrm{Noxl}^{-/ Y}$ compared with responses in Nox $1^{+/ Y}$ when responses to acute thermal stimuli were examined by tail flick $\left(5.96 \pm 0.47 \mathrm{~s}\right.$ latency in $N o x 1^{+/ Y}$ vs $5.93 \pm 0.38 \mathrm{~s}$ in Noxi ${ }^{-/ Y} ; n=8-10$ ) and hotplate tests (Fig. 2a). Furthermore, no significant difference in the threshold for mechanical stimuli was observed between the two genotypes $\left(106.12 \pm 8.35 \mathrm{~g}\right.$ in Nox1 $1^{+/ Y}$ vs $98.63 \pm 6.25 \mathrm{~g}$ in Nox1 $\left.{ }^{-/ Y} ; n=8-10\right)$. We subsequently analyzed the response to chemical stimuli by injecting Formalin into the hindpaw. In this model, a biphasic response is observed. In phase 1 , Formalin directly stimulates nociceptors to induce the pain response, and, in phase 2 , the subsequently induced inflammation elicits the pain response (Tjolsen and Hole, 1992). As determined by the licking/biting response time, the phase 1 responses were similar between the genotypes. In phase 2, however, a significant reduction in licking time was observed in $\mathrm{Nox}^{-/ Y}$ (Fig. 2b). Intraperitoneal injection of acetic acid induces a typical behavior (writhing) in mice, which is used for quantifying visceral pain with inflammation (Tjolsen and Hole, 1992). When mice were injected with acetic acid, the number of writhes in Nox $1^{-/ Y}$ was significantly diminished compared with that in Noxl $^{+/ Y}\left(31.7 \pm 2.45\right.$ in Nox1 ${ }^{+/ Y}$ vs $23.2 \pm 1.87$ in Nox1 ${ }^{-/ Y}$; $p<$ $0.01 ; n=8-10)$. Accordingly, the pain response after direct stimulation of nociceptors by Formalin was not affected, whereas the response during the chemical-induced inflammation appeared to be significantly attenuated in $\mathrm{Nox}^{-/ Y}$.

\section{Inflammatory pain is attenuated in Nox $1^{-/ Y}$}

To further verify the findings obtained by chemical stimuli that elicit inflammatory responses, we next studied another model of inflammatory pain. Intraplantar injection of carrageenan into the hindpaw induced a time-dependent development of edema and hyperalgesia. In $\mathrm{Noxl}^{-/ Y}$, carrageenan similarly evoked marked edema at $1 \mathrm{~h}$ after administration, which persisted until $5 \mathrm{~h}$ (Fig. 3a). Conversely, the development of thermal and mechanical hyperalgesia was significantly attenuated in $\mathrm{Nox}^{-/ Y}$ compared with $\mathrm{Noxl}^{+/ Y}$ (Fig. 3b,c). These findings suggest that ROS derived from NOX1/NADPH oxidase affect the response properties of nociceptor afferents under inflammatory conditions.

\section{Augmentation in the capsaicin-induced calcium increase by chemical mediators is attenuated in $\mathrm{Noxi}^{-/ Y}$}

Posttranslational modifications and transcriptional changes of nociceptors alter their threshold and excitability, leading to pain hypersensitivity. Nociceptor afferent terminals transduce noxious stimuli into electrical activity, which is conducted to the dorsal horn of the spinal cord. To further delineate the molecular mechanisms underlying the reduced hyperalgesia observed in Nox1 $1^{-/ Y}$, we isolated DRG containing cell bodies of afferent neurons. Because TRPV1, which works as an inflammatory sensor, has been implicated in the development of thermal hyperalgesia, we focused on TRPV1 activity in DRG neurons. Previously it was reported that NOX2/NADPH oxidase mediates NGF-induced increase in TRPV1 protein expression in rat PC12 cells (Puntambekar et al., 2005). We therefore examined the level of TRPV1 protein expressed in DRG neurons. Densitometric analyses of immunoblots indicated that the level of TRPV1 protein in DRG neurons of $\mathrm{NoxI}^{-/ Y}$ was comparable with that in the neurons of $\operatorname{Noxl}^{+/ Y}$ (data not shown).

Capsaicin, an agonist of TRPV1, dose dependently increased intracellular calcium levels in DRG neurons of both genotypes in a similar manner (Fig. 4a). The expression level and function of TRPV1 in DRG neurons are therefore unaffected in Nox1 ${ }^{-/ Y}$. In the development of hyperalgesia, PKA and PKC are known to participate in the activation of TRPV1 (Cesare et al., 1999; Bhave et al., 2002). As shown in Figure 4b, forskolin and a phorbol ester, PMA, known to activate PKA and PKC, respectively, markedly augmented the increase in calcium induced by capsaicin. Although no difference in the effect of forskolin was observed between the genotypes, the effect of PMA was significantly attenuated in Nox1 ${ }^{-Y Y}$ DRG neurons. Bradykinin and serotonin are inflammatory mediators that increase the heat response via activation of the PKC-dependent signaling pathway (Cesare et al., 1999; Numazaki et al., 2002). The finding obtained with PMA was thus verified by applying these inflammatory mediators to DRG neurons. As shown in Figure 4c, bradykinin or serotonin alone moderately increased the level of intracellular calcium in both genotypes to the same extent. In $N o x 1^{+/ Y}$ neurons, the capsaicin-induced calcium increase was markedly augmented in the presence of bradykinin or serotonin, whereas such an increase was abolished in Nox1 ${ }^{-/ Y}$ DRG neurons. Accordingly, the absence of NOX1/NADPH oxidase affects the PKC-dependent activation of TRPV1, downstream of the receptor for inflammatory mediators. 

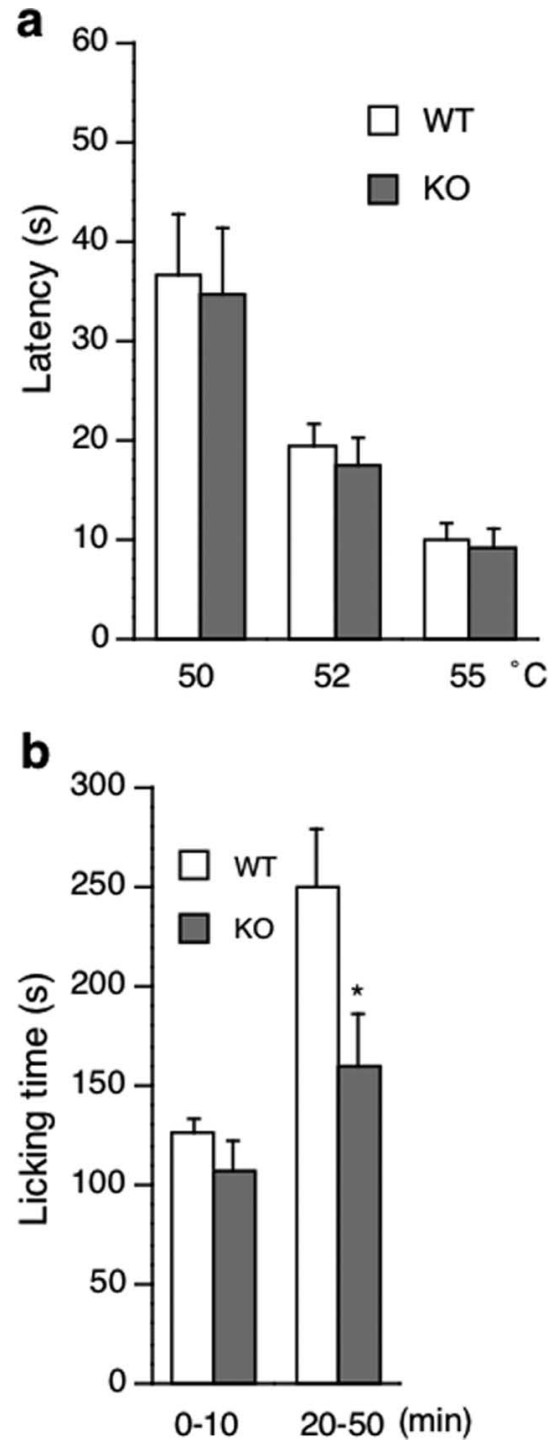

Figure 2. Thermal and chemical nociception in $\operatorname{Nox}^{+/ N}$ and Nox $1^{-N}$. $a$, Latency for hindpaw licking and/or jumping in hotplate tests; $\boldsymbol{b}$, the licking and/or biting time $0-10$ and $20-50$ min after Formalin was injected to the hindpaw. WT (wild-type) and KO (knock-out) represent control littermate $\left(\mathrm{Nox}^{+/ Y}\right)$ and Nox1-deficient $\left(\mathrm{Nox}^{-N}\right)$ mice, respectively. Values were obtained from 8 to 10 animals per group. ${ }^{*} p<0.05$, compared with WT.

PMA-induced translocation of PKC $\varepsilon$ is attenuated in $N o x 1^{-/ Y}$ To delineate the role of NOX1/NADPH oxidase in the PKCdependent activation of TRPV1, we next examined the translocation of PKC $\varepsilon$ in DRG neurons. The bradykinin-induced TRPV1 activation is dependent on the PKC $\varepsilon$ pathway (Cesare et al., 1999; Puntambekar et al., 2005), and direct phosphorylation of the serine residues of TRPV1 by PKC $\varepsilon$ increases the channel activity (Numazaki et al., 2002). Exposure of DRG neurons isolated from $\mathrm{Nox}^{+/ Y}$ to PMA markedly increased the translocation of PKC $\varepsilon$ from the cytosolic to membrane fractions. In contrast, PMA-induced PKC $\varepsilon$ translocation was significantly perturbed in DRG neurons of $\operatorname{Nox1}^{-/ Y}$ (Fig. 5a). Because ROS derived from NOX1/NADPH oxidase may affect the membrane translocation of other PKC isoforms implicated in hyperalgesia (Olah et al., 2002; Obreja et al., 2005), we examined the translocation of $\mathrm{PKC} \alpha$ and $\mathrm{PKC} \delta$ in DRG neurons. Interestingly, PMA-induced translocations of $\mathrm{PKC} \alpha$ and $\mathrm{PKC} \delta$ were similarly reduced in Nox $1^{-/ Y}$ DRG neurons. When Nox $1^{+/ Y}$ neurons were pretreated

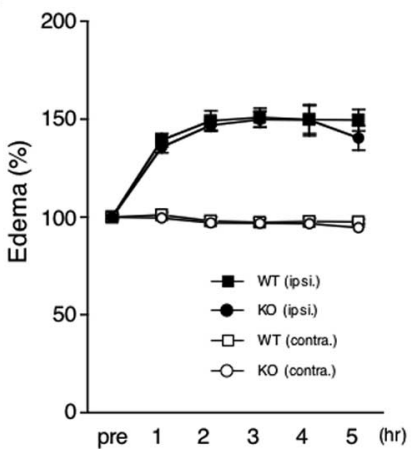

b

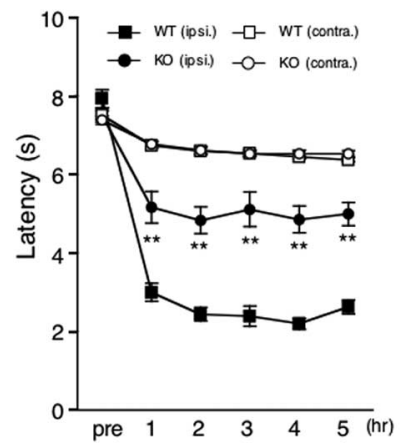

C

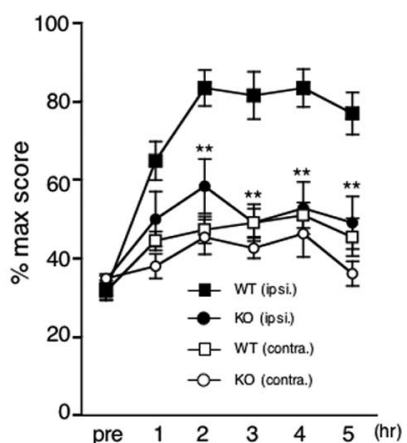

Figure 3. Carrageenan-induced inflammatory pain is attenuated in $\operatorname{Nox}^{-/ Y}$. $\boldsymbol{a}$, Development of edema after intraplantar injection of carrageenan; $\boldsymbol{b}$, the hindpaw withdrawal latency for thermal stimuli; $c$, the pain score determined with the von Frey test. Thermal and mechanical hyperalgesia were significantly attenuated in $\mathrm{Nox}^{-/ \gamma}$. Filled and open squares indicate ipsilateral and contralateral hindpaws of $\mathrm{Nox}^{+N}$, and filled and open circles indicate ipsilateral and contralateral hindpaws of $\mathrm{Nox}^{-/ \gamma}$ (KO, for knock-out), respectively. Values were obtained from eight to nine animals per group. ${ }^{* *} p<0.01$, compared with the ipsilateral hindpaw of Nox $1^{+N}$ (WT, for wild-type).

with a compound that mimics the activity of SOD or catalase, the translocation of PKC $\varepsilon$ induced by PMA was significantly attenuated. Similar results were obtained when $N o x 1^{+/ Y}$ neurons were pretreated with a sulfhydryl protective agent, $\mathrm{N}$-acetyl cysteine or dithiothreitol (Fig. 5b). These findings suggest that ROS derived from NOX1/NADPH oxidase modulate the translocation and activation of PKC $\varepsilon$ in DRG neurons.

Oxidation of sulfhydryl residues of the $\mathrm{C} 1 \mathrm{~A}$ domain enhances the translocation of $\mathrm{PKC} \varepsilon$

We then investigated the molecular mechanisms underlying the reduced translocation of PKC $\varepsilon$ in $N o x 1^{-/ Y}$ DRG neurons. It has been suggested that ROS activate PKC isoforms through posttranslational modifications. During treatment of cells with hydrogen peroxide, $\mathrm{PKC}$ isoforms including $\mathrm{PKC} \varepsilon$ are phosphorylated at the tyrosine residues conserved in the catalytic domain of the PKC family and enzymatically activated (Konishi et al., 1997). We first examined whether PKC $\varepsilon$ is tyrosine phosphorylated during stimulation and translocation to plasma membranes using a specific antiphosphorylated tyrosine antibody. However, no difference was observed in the phosphorylation of tyrosine residues of PKC $\varepsilon$ in HEK293 cells exposed to hydrogen peroxide (data not shown). Another mechanism underlying the ROSinduced activation of $\mathrm{PKC}$ is reported for the conventional PKC isoform containing both the $\mathrm{C} 1$ and $\mathrm{C} 2$ motifs (Knapp and Klann, 2000; Lin and Takemoto, 2005). Because the C1 motif containing two lipid-binding sites, $\mathrm{C} 1 \mathrm{~A}$ and $\mathrm{C} 1 \mathrm{~B}$, is conserved in 
a
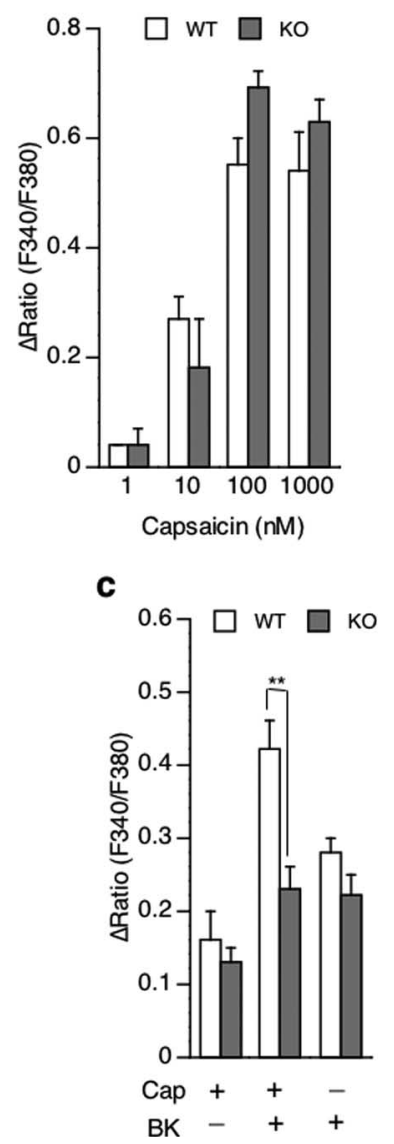

b

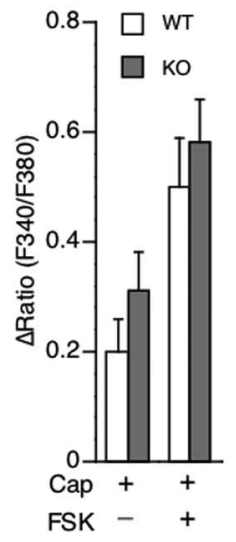

Figure 4. Augmentation of the capsaicin-induced calcium increase by chemical mediators is blunted in Nox ${ }^{-/ Y}$ DRG neurons. $\boldsymbol{a}$, Functional characterization of TRPV1. Capsaicin, an agonist of TRPV1, dose dependently increased intracellular calcium levels in DRG neurons of both genotypes. Values were obtained from four to six experiments. $\boldsymbol{b}$, Effects of forskolin $(10 \mu \mathrm{M})$ or PMA (100 nm) on capsaicin-induced increase in intracellular calcium. c, Effects of bradykinin (10 $\mu \mathrm{M})$ or serotonin $(30 \mu \mathrm{m})$ on capsaicin-induced increase in intracellular calcium. Forskolin (FSK), PMA, bradykinin (BK), or serotonin (5-HT) was applied before the addition of capsaicin (Cap). Values were obtained from four to eight experiments. ${ }^{*} p<0.05$; ${ }^{* *} p<0.01$.

$\mathrm{PKC} \varepsilon$, direct oxidation of $\mathrm{PKC} \varepsilon$ and possibly other $\mathrm{PKC}$ isoforms in DRG neurons at the $\mathrm{C} 1$ domain may accelerate translocation of the domain to plasma membranes. We therefore transfected HEK293 cells with a GFP-fused full-length PKC $\varepsilon$ or deletion mutant lacking the $\mathrm{C} 1 \mathrm{~A}(\Delta \mathrm{C} 1 \mathrm{~A})$ or $\mathrm{C} 1 \mathrm{~B}(\Delta \mathrm{C} 1 \mathrm{~B})$ domain and exposed them to hydrogen peroxide. Treatment with hydrogen peroxide reduced free sulfhydryl groups of full-length PKC $\varepsilon$, as well as of the deletion mutant lacking the $\mathrm{C} 1 \mathrm{~B}$ site $(\Delta \mathrm{C} 1 \mathrm{~B})$. Conversely, the level of free sulfhydryl groups was unaffected in the $\mathrm{C} 1 \mathrm{~A}$ deletion mutant $(\triangle \mathrm{C} 1 \mathrm{~A})$ treated with hydrogen peroxide (Fig. 6a). We then transfected $\mathrm{CHO}$ cells with full-length $\mathrm{PKC} \varepsilon-$ GFP or $\triangle \mathrm{C} 1 \mathrm{~A}-\mathrm{GFP}$ and stimulated with hydrogen peroxide or with PMA. Hydrogen peroxide induced translocation of fulllength PKC $\varepsilon$ to plasma membranes, whereas translocation of $\Delta \mathrm{C} 1 \mathrm{~A}$ was significantly reduced (Fig. $6 b$ ). In contrast to these findings, PMA-induced translocation of $\triangle \mathrm{C} 1 \mathrm{~A}$ was retained as observed previously (Kashiwagi et al., 2002). These findings suggest that ROS derived from NOX1/NADPH oxidase enhance the translocation of PKC $\varepsilon$ via modulation of the redox state of cysteine residues located at the $\mathrm{C} 1 \mathrm{~A}$ site.

\section{Discussion}

We demonstrated a new function of NOX1/NADPH oxidase in the development of inflammatory pain. The principal findings obtained include the following. (1) Thermal and mechanical hyperalgesia was significantly attenuated in $\mathrm{Noxl}^{-/ Y}$, whereas no difference in nociceptive responses to heat or mechanical stimuli

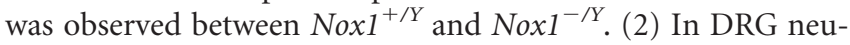
rons derived from $\mathrm{Noxl}^{+/ Y}$, pretreatment of bradykinin, serotonin, or PMA augmented the capsaicin-induced increase in calcium, whereas this increase was significantly attenuated in $N o x 1^{-/ Y}$. (3) PMA-induced translocation of PKC $\varepsilon$ was significantly reduced in $N o x 1^{-/ Y}$ or in $N o x 1^{+/ Y}$ neurons treated with ROS-scavenging agents. (4) In cells transfected with tagged $\mathrm{PKC} \varepsilon$, hydrogen peroxide induced translocation and a reduction in free sulfhydryls of full-length PKC $\varepsilon$ but not of the deletion mutant lacking the C1A domain. These results suggest that ROS derived from NOX1/NADPH oxidase oxidize the C1A domain of PKC $\varepsilon$ and accelerate the translocation to plasma membranes of DRG neurons, thereby enhancing the TRPV1 activity and the sensitivity to painful stimuli.

Between $\mathrm{Noxl}^{+/ Y}$ and $\mathrm{Noxl}^{-/ Y}$, no significant difference was demonstrated in the size distribution of DRG neurons or the population of TRPV1-positive neurons. These histological findings did not reflect our previous study, indicating a regulatory role for NOX1 in NGF-induced neurite outgrowth in cultured PC12 cells (Ibi et al., 2006). Quantitative mRNA analyses of Nox ${ }^{+/ Y}$ DRG verified expression of Noxl together with expression of other isoforms of NADPH oxidase, Nox2 and Nox4. We could not, however, confirm the localization and distribution of NOX1 protein in DRG using immunohistochemical techniques. This could be attributed to the low level of protein expressed in DRG compared with colon epithelial cells in which abundant expression of NOX1 is reported (Szanto et al., 2005). Conversely, the reduced production of superoxide demonstrated in $\mathrm{Noxl}^{-/ Y}$ clearly indicated the functional contribution of NOX1/NADPH oxidase to ROS generated in DRG neurons. The level of Nox1 mRNA expressed in the paws was much higher than the level in DRG. Because abundant expression of NOX1 is reported in colon epithelial cells and also observed in pulmonary tissue (K. Iwata and K. Matsuno, unpublished data), NOX1 might be preferentially localized in the tissue exposed to environmental irritants.

We presently showed that ROS derived from NOX1/NADPH oxidase in DRG neurons play a crucial role in the development of hyperalgesia using Nox1-deficient mice. In contrast, it was reported that ROS generated in mitochondria of the dorsal horn neurons mediate the development of inflammatory hyperalgesia evoked by carrageenan (Wang et al., 2004). Inactivation of mitochondrial SOD induced by superoxide was a key event in this hyperalgesic response, by allowing the levels of superoxide to remain elevated and maintain nociceptive signaling. In fact, intrathecal administration of an SOD mimetic completely reversed hyperalgesia (Wang et al., 2004). Inactivation of spinal MnSOD was demonstrated in NMDA-mediated hyperalgesia as well (Muscoli et al., 2004), and ROS generated in mitochondria were further implicated in the development of capsaicin-induced hyperalgesia (Schwartz et al., 2008). It is well known that, during tissue injury and inflammation, hyperalgesia results from a persistent state of peripheral afferent sensitization that subsequently initiates spinal sensitization. Accordingly, oxidative stress in the spinal cord might be also reduced as a result of decreased peripheral sensitization in $\mathrm{Nox}^{-/ Y}$. The data presented here, together with those of preceding studies, suggest that ROS formed at mul- 
tiple levels of the nociceptive signaling cascade may contribute to the development of hyperalgesia.

In our study, both $N o x 1^{+/ Y}$ and Nox $1^{-/ Y}$ developed edema to a similar extent, whereas ROS scavengers are documented to ameliorate edema as well as hyperalgesia (Wang et al., 2004; Khattab, 2006). Because inflammatory cells such as neutrophil and macrophage predominantly express NOX2 and produce a large amount of ROS under inflammatory conditions, it is reasonable to assume that ROS derived from NOX2/NADPH oxidase may be involved in the development of edema. Conversely, our present findings indicate that ROS derived from NOX1/NADPH oxidase take part in the development of hyperalgesia.

Several lines of evidence indicate that glial cells are important in the development of hyperalgesia. Indeed, intrathecal administration of agents that disrupt glial function or disrupt the action of glial products blocked Formalin-induced hyperalgesia in rats (Watkins et al., 1997). Recent investigation of hyperalgesia at the spinal transcriptome level indicated that carrageenan-induced inflammation of rat hindpaws leads to a rapid but sustained increase in S100A8 and S100A9 expression, two members of the S100 family implicated in the pathology of numerous inflammatory diseases (Mitchell et al., 2008). These proinflammatory genes derived from a population of neutrophils that mobilized to the spinal cord. Because NOX2 is predominantly expressed in glial cells and neutrophils, it is surprising that NOX1 was shown to be the major isoform involved in the development of Formalin- and carrageenan-induced hyperalgesia. Our findings might be attributed to the close proximity between NOX1/NADPH oxidase and the target molecule identified in this study, which enables direct interaction and modulation of TRPV1 activity in DRG neurons.

Chemical mediators released from damaged tissue and inflammatory cells decrease the activation threshold of TRPV1 via phosphorylation of serine residues in a PKA- or PKC-dependent manner (Bhave et al., 2002; Numazaki et al., 2002). In this study, no difference in the effect of forskolin, an activator of PKA, on capsaicin-induced TRPV1 activation was observed between the genotypes, whereas the effect of PMA was significantly attenuated in Nox $1^{-/ Y}$ DRG neurons. Moreover, PMA-induced translocation of PKC was significantly reduced in Nox1 $1^{-/ Y}$ neurons. ROS derived from NOX1/NADPH oxidase were thus suggested to modulate TRPV1 activity in a PKC-dependent manner. In cells exposed to ROS, PKC isoforms including $\mathrm{PKC} \varepsilon$ are phosphorylated at the tyrosine residues conserved in the catalytic domain of the PKC family and enzymatically activated (Konishi et al., 1997). Although we initially examined whether PKC $\varepsilon$ is tyrosine phos- cont PMA
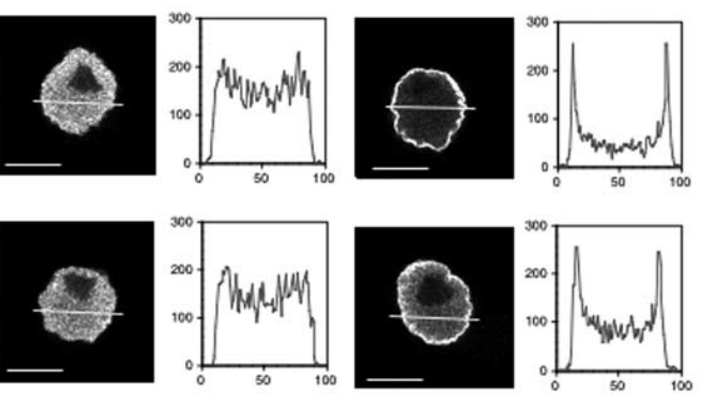

PKC $\varepsilon$

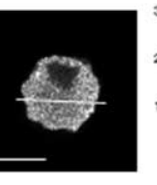

PKC $\alpha$
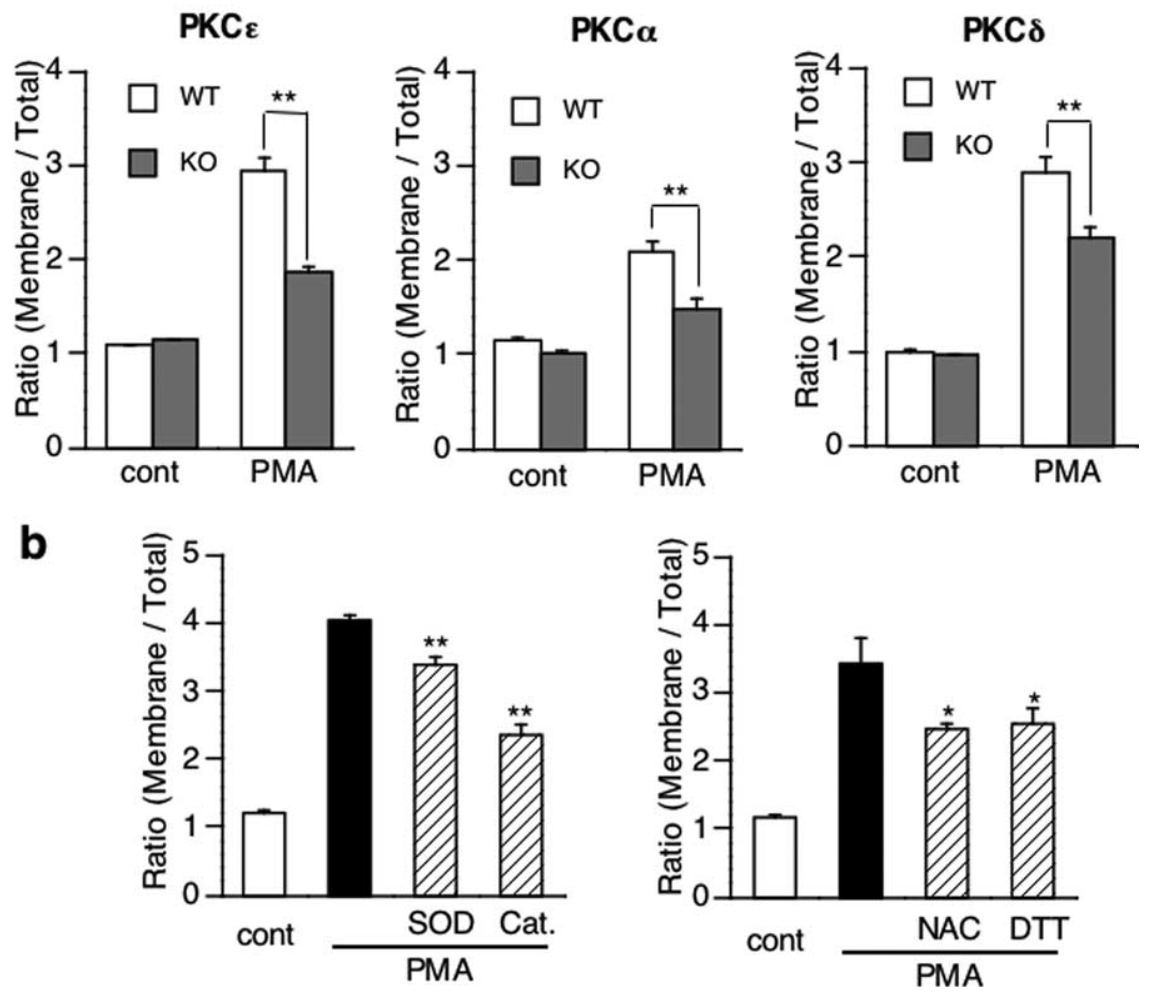

Figure 5. PMA-induced translocation of PKC is attenuated in Nox $1^{-/ Y}$ DRG neurons. $\boldsymbol{a}$, Representative photographs and fluorescence intensity histograms of PKC. Top row demonstrates localization of PKC $\varepsilon$ in DRG neurons. The histogram is taken at a on PMA-induced PKC $\varepsilon$ translocation. Three hours before the addition of $100 \mathrm{~nm} \mathrm{PMA,} 300 \mathrm{mU} / \mathrm{ml} \mathrm{SOD-PEG} \mathrm{(SOD),} 300 \mathrm{mU} / \mathrm{ml}$ $0.05,{ }^{* *} p<0.01$, compared with PMA alone. WT (wild-type) and KO (knock-out) represent control littermate (Nox $1^{+/ Y}$ ) and Nox1-deficient $\left(\operatorname{Nox}^{-/ Y}\right)$ mice, respectively. 
a

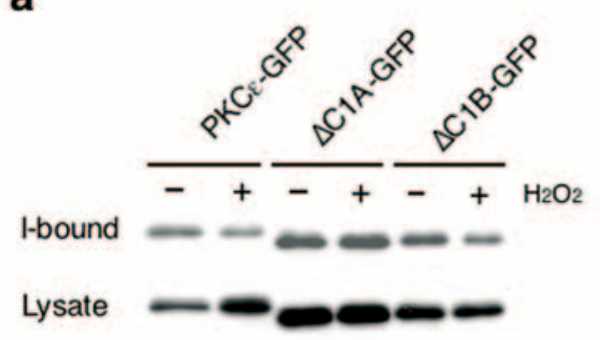

b
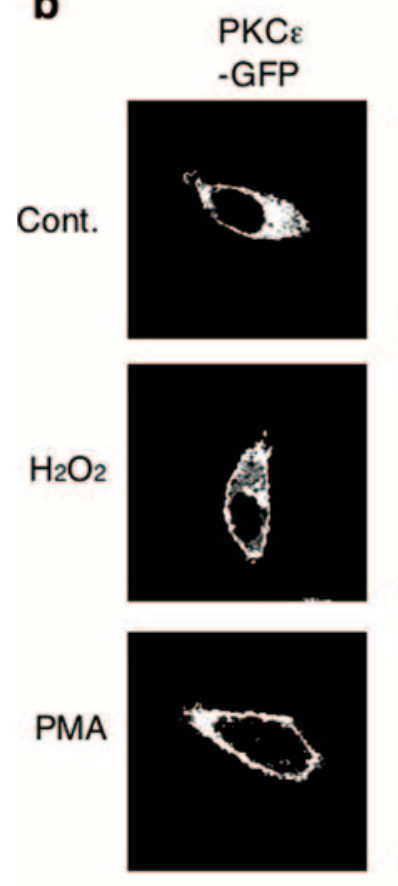
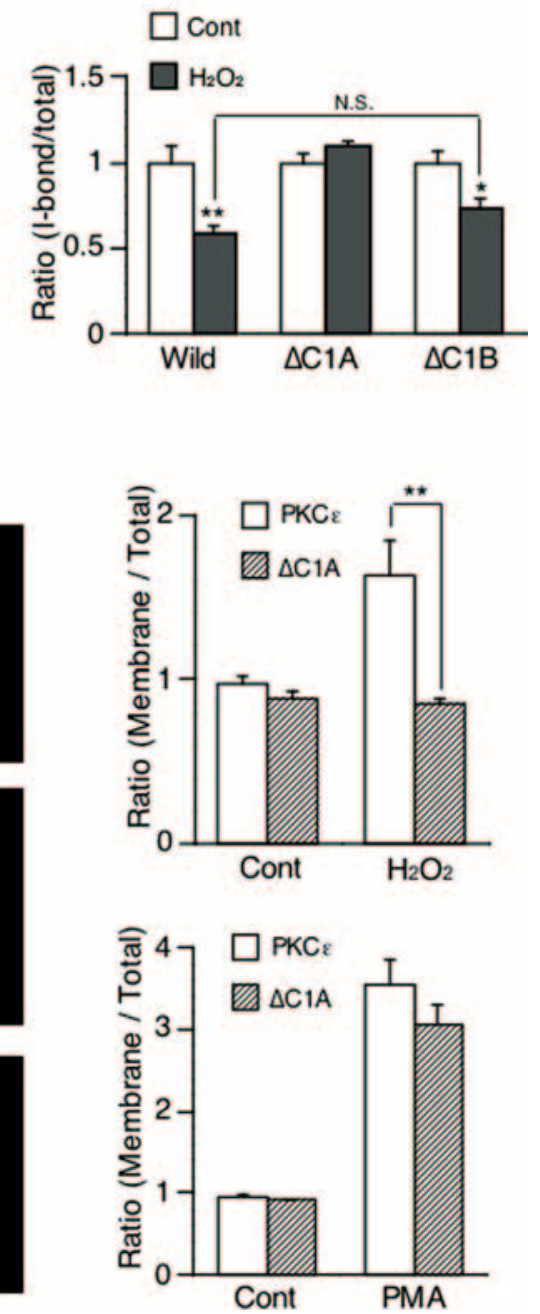

Figure 6. Involvement of the redox state of sulfhydryl residues in the C1A domain of PKC $\varepsilon$. $a$, Determination of free sulfhydryl residues in PKC $\varepsilon$ and deletion mutants after $\mathrm{H}_{2} \mathrm{O}_{2}$ treatment. HEK293 cells transfected with a GFP-fused full-length PKC $\varepsilon$ or deletion mutant lacking the $\mathrm{C} 1 \mathrm{~A}(\Delta C 1 \mathrm{~A})$ or $\mathrm{C} 1 \mathrm{~B}(\Delta \mathrm{C} 1 \mathrm{~B})$ domain were exposed to $100 \mu \mathrm{M} \mathrm{H}_{2} \mathrm{O}_{2}$ for $5 \mathrm{~min}$. Top row demonstrates iodoacetyl-PEO ${ }_{2}$ biotin-bound PKC $\varepsilon$ (I-bound), which corresponds to the enzyme containing reduced cysteine residues. Bottom row indicates the total PKC $\varepsilon$ level in the lysate. Right demonstrates quantitative densitometric analysis of the ratio of I-bound to total PKC $\varepsilon$. Results are representative of five independent experiments. ${ }^{*} p<0.05,{ }^{* *} p<0.01$, compared with control. N.S., Not significant. $\boldsymbol{b}$, Translocation of PKC $\varepsilon$ induced by $\mathrm{H}_{2} \mathrm{O}_{2}$ or PMA. CHO cells transfected with full-length PKC $\varepsilon-G F P$ or $\triangle C 1 A-G F P$ were stimulated with $100 \mu \mathrm{M} \mathrm{H}_{2} \mathrm{O}_{2}$ for 2 min or with $1 \mu \mathrm{M}$ PMA for $10 \mathrm{~min}$. Scale bar, $10 \mu \mathrm{m}$. Representative photographs of three experiments are shown (left). Right demonstrates quantitative measurements of the fluorescence intensity of PKC $\varepsilon-G F P$ or $\Delta$ C1A-GFP. ${ }^{* *} p<0.01$. Values were obtained from 9 to 18 neurons.

fected with the tagged PKC $\varepsilon$ construct. These findings suggest that ROS derived from NOX1/NADPH oxidase enhance the translocation of PKC $\varepsilon$ via modulation of the redox state of cysteine residues located at the $\mathrm{C} 1 \mathrm{~A}$ site.

It has been reported that various inflammatory factors are involved in hyperalgesia via a sequential activation of PKC $\varepsilon$ and TRPV1 (Cesare and McNaughton, 1996; Khasar et al., 1999; Chuang et al., 2001; Zhang et al., 2005; Amadesi et al., 2006; Ohta et al., 2006). Meanwhile, the modification of reactive cysteine residues of TRP channels is documented to cause channel activation. Given that oxidative modifications ( $S$-oxidation) of cysteine residues by hydrogen peroxide were shown to activate TRPV1 (Yoshida et al., 2006), ROS derived from NOX1/NADPH oxidase might also interact with TRPV1 to regulate the channel activity. The possibility of direct oxidative modifications of TRPV1 by NOX1/NADPH oxidase remains under consideration.

In conclusion, we demonstrated a novel role for NOX1/

NADPH oxidase in the development of thermal and mechanical hyperalgesia. ROS derived from NOX1/NADPH oxidase accelerate the translocation of PKC and augment TRPV1 activity in DRG neurons. The present study provides the first evidence that NOX1/NADPH oxidase is a source of ROS implicated in inflammatory pain, thus making it a novel target for future therapeutic strategies.

\section{References}

Abramov AY, Canevari L, Duchen MR (2004) $\beta$-Amyloid peptides induce mitochondrial dysfunction and oxidative stress in astrocytes and death of neurons through activation of NADPH oxidase. J Neurosci 24:565-575.

Amadesi S, Cottrell GS, Divino L, Chapman K, Grady EF, Bautista F, Karanjia R, BarajasLopez C, Vanner S, Vergnolle N, Bunnett NW (2006) Protease-activated receptor 2 sensitizes TRPV1 by protein kinase Cepsilon- and A-dependent mechanisms in rats and mice. J Physiol 575:555-571.

Bhave G, Zhu W, Wang H, Brasier DJ, Oxford GS, Gereau RW 4th (2002) cAMP-dependent protein kinase regulates desensitization of the capsaicin receptor (VR1) by direct phosphorylation. Neuron 35:721-731.

Caterina MJ, Leffler A, Malmberg AB, Martin WJ, Trafton J, Petersen-Zeitz KR, Koltzenburg M, Basbaum AI, Julius D (2000) Impaired nociception and pain sensation in mice lacking the capsaicin receptor. Science 288:306-313.

Cesare P, McNaughton P (1996) A novel heatactivated current in nociceptive neurons and its sensitization by bradykinin. Proc Natl Acad Sci U S A 93:15435-15439.

Cesare P, Dekker LV, Sardini A, Parker PJ, McNaughton PA (1999) Specific involvement of PKC-epsilon in sensitization of the neuronal response to painful heat. Neuron 23:617-624.

Chuang HH, Prescott ED, Kong H, Shields S, Jordt SE, Basbaum AI, Chao MV, Julius D (2001) Bradykinin and nerve growth factor release the capsaicin receptor from $\operatorname{PtdIns}(4,5) \mathrm{P} 2$ mediated inhibition. Nature 411:957-962.

Hargreaves K, Dubner R, Brown F, Flores C, Joris J (1988) A new and sensitive method for measuring thermal nociception in cutaneous hyperalgesia. Pain 32:77-88.

Hu HJ, Bhave G, Gereau RW 4th (2002) Prostaglandin and protein kinase A-dependent modulation of vanilloid receptor function by metabotropic glutamate receptor 5: potential mechanism for thermal hyperalgesia. J Neurosci 22:7444-7452.

Ibi M, Katsuyama M, Fan C, Iwata K, Nishinaka T, Yokoyama T, YabeNishimura C (2006) NOX1/NADPH oxidase negatively regulates nerve growth factor-induced neurite outgrowth. Free Radic Biol Med 40:1785-1795.

Kashiwagi K, Shirai Y, Kuriyama M, Sakai N, Saito N (2002) Importance of C1B domain for lipid messenger-induced targeting of protein kinase C. J Biol Chem 277:18037-18045.

Khasar SG, Lin YH, Martin A, Dadgar J, McMahon T, Wang D, Hundle B, Aley KO, Isenberg W, McCarter G, Green PG, Hodge CW, Levine JD, Messing RO (1999) A novel nociceptor signaling pathway revealed in protein kinase C epsilon mutant mice. Neuron 24:253-260.

Khattab MM (2006) TEMPOL, a membrane-permeable radical scavenger, attenuates peroxynitrite- and superoxide anion-enhanced carrageenaninduced paw edema and hyperalgesia: a key role for superoxide anion. Eur J Pharmacol 548:167-173.

Kim KY, Rhim T, Choi I, Kim SS (2001) N-acetylcysteine induces cell cycle 
arrest in hepatic stellate cells through its reducing activity. J Biol Chem 276:40591-40598.

Knapp LT, Klann E (2000) Superoxide-induced stimulation of protein kinase $\mathrm{C}$ via thiol modification and modulation of zinc content. J Biol Chem 275:24136-24145.

Konishi H, Tanaka M, Takemura Y, Matsuzaki H, Ono Y, Kikkawa U, Nishizuka Y (1997) Activation of protein kinase C by tyrosine phosphorylation in response to $\mathrm{H}_{2} \mathrm{O}_{2}$. Proc Natl Acad Sci U S A 94:11233-11237.

Kuribara H, Higuchi Y, Tadokoro S (1977) Effects of central depressants on rota-rod and traction performances in mice. Jpn J Pharmacol 27:117-126.

Lambeth JD (2004) NOX enzymes and the biology of reactive oxygen. Nat Rev Immunol 4:181-189.

Lin D, Takemoto DJ (2005) Oxidative activation of protein kinase Cgamma through the $\mathrm{Cl}$ domain. Effects on gap junctions. J Biol Chem 280:13682-13693.

Matsuno K, Yamada H, Iwata K, Jin D, Katsuyama M, Matsuki M, Takai S, Yamanishi K, Miyazaki M, Matsubara H, Yabe-Nishimura C (2005) Noxl is involved in angiotensin II-mediated hypertension: a study in Nox1-deficient mice. Circulation 112:2677-2685.

Mitchell K, Yang HY, Tessier PA, Muhly WT, Swaim WD, Szalayova I, Keller JM, Mezey E, Iadarola MJ (2008) Localization of S100A8 and S100A9 expressing neutrophils to spinal cord during peripheral tissue inflammation. Pain 134:216-231.

Muscoli C, Mollace V, Wheatley J, Masini E, Ndengele M, Wang ZQ, Salvemini D (2004) Superoxide-mediated nitration of spinal manganese superoxide dismutase: a novel pathway in $N$-methyl-D-aspartatemediated hyperalgesia. Pain 111:96-103.

Numazaki M, Tominaga T, Toyooka H, Tominaga M (2002) Direct phosphorylation of capsaicin receptor VR1 by protein kinase Cepsilon and identification of two target serine residues. J Biol Chem 277:13375-13378.

Obreja O, Biasio W, Andratsch M, Lips KS, Rathee PK, Ludwig A, Rose-John S, Kress M (2005) Fast modulation of heat-activated ionic current by proinflammatory interleukin 6 in rat sensory neurons. Brain 128:1634-1641.

Ohta T, Ikemi Y, Murakami M, Imagawa T, Otsuguro K, Ito S (2006) Potentiation of transient receptor potential V1 functions by the activation of metabotropic 5-HT receptors in rat primary sensory neurons. J Physiol 576:809-822.

Olah Z, Karai L, Iadarola MJ (2002) Protein kinase Ca is required for vanilloid receptor 1 activation. J Biol Chem 277:35752-35759.

Puntambekar P, Mukherjea D, Jajoo S, Ramkumar V (2005) Essential role of Rac1/NADPH oxidase in nerve growth factor induction of TRPV1 expression. J Neurochem 95:1689-1703.

Rathee PK, Distler C, Obreja O, Neuhuber W, Wang GK, Wang SY, Nau C, Kress M (2002) PKA/AKAP/VR-1 module: a common link of Gsmediated signaling to thermal hyperalgesia. J Neurosci 22:4740-4745.
Salvemini D, Wang ZQ, Bourdon DM, Stern MK, Currie MG, Manning PT (1996) Evidence of peroxynitrite involvement in the carrageenaninduced rat paw edema. Eur J Pharmacol 303:217-220.

Sango K, Tokashiki A, Ajiki K, Horie M, Kawano H, Watabe K, Horie H, Kadoya T (2004) Synthesis, localization and externalization of galectin-1 in mature dorsal root ganglion neurons and Schwann cells. Eur J Neurosci 19:55-64.

Schwartz ES, Lee I, Chung K, Chung JM (2008) Oxidative stress in the spinal cord is an important contributor in capsaicin-induced mechanical secondary hyperalgesia in mice. Pain, in press.

Szanto I, Rubbia-Brandt L, Kiss P, Steger K, Banfi B, Kovari E, Herrmann F, Hadengue A, Krause KH (2005) Expression of NOX1, a superoxidegenerating NADPH oxidase, in colon cancer and inflammatory bowel disease. J Pathol 207:164-176.

Takasaki I, Andoh T, Shiraki K, Kuraishi Y (2000) Allodynia and hyperalgesia induced by herpes simplex virus type- 1 infection in mice. Pain 86:95-101.

Tjolsen T, Hole K (1992) Animal models of analgesia. In: The pharmacology of pain (Dickenson A, Besson JM, eds), pp 1-20. Berlin: Springer.

Tominaga M, Caterina MJ, Malmberg AB, Rosen TA, Gilbert H, Skinner K, Raumann BE, Basbaum AI, Julius D (1998) The cloned capsaicin receptor integrates multiple pain-producing stimuli. Neuron 21:531-543.

Wang ZQ, Porreca F, Cuzzocrea S, Galen K, Lightfoot R, Masini E, Muscoli C, Mollace V, Ndengele M, Ischiropoulos H, Salvemini D (2004) A newly identified role for superoxide in inflammatory pain. J Pharmacol Exp Ther 309:869-878.

Watkins LR, Martin D, Ulrich P, Tracey KJ, Maier SF (1997) Evidence for the involvement of spinal cord glia in subcutaneous formalin induced hyperalgesia in the rat. Pain 71:225-235.

Wu DC, Jackson-Lewis V, Vila M, Tieu K, Teismann P, Vadseth C, Choi DK, Ischiropoulos H, Przedborski S (2002) Blockade of microglial activation is neuroprotective in the 1-methyl-4-phenyl-1,2,3,6-tetrahydropyridine mouse model of Parkinson disease. J Neurosci 22:1763-1771.

Wu DC, Ré DB, Nagai M, Ischiropoulos H, Przedborski S (2006) The inflammatory NADPH oxidase enzyme modulates motor neuron degeneration in amyotrophic lateral sclerosis mice. Proc Natl Acad Sci U S A 103:12132-12137.

Yoshida T, Inoue R, Morii T, Takahashi N, Yamamoto S, Hara Y, Tominaga M, Shimizu S, Sato Y, Mori Y (2006) Nitric oxide activates TRP channels by cysteine S-nitrosylation. Nat Chem Biol 2:596-607.

Zhang N, Inan S, Cowan A, Sun R, Wang JM, Rogers TJ, Caterina M, Oppenheim JJ (2005) A proinflammatory chemokine, CCL3, sensitizes the heat- and capsaicin-gated ion channel TRPV1. Proc Natl Acad Sci U S A 102:4536-4541. 